\title{
Peter Maxwell Davies' Interpretation of Past Musical Practices in Naxos Quartet No. 8
}

\author{
Kheng K. Koay
}

Peter Maxwell Davies (1934-2016), an English composer, often wrote challenging pieces that projected his surroundings, culture and musical training. Throughout his creative career, Davies never short of musical ideas, and never strove to write compositions in prevailing or emerging musical trends. As he once claimed, "I have so many ideas for pieces of music that I want to write before I'm too senile to be able to do it," ${ }^{1}$ and "I get very suspicious of people who say that in the twenty-first century, music must be this, that, and the other." Indeed, his music covers a wide range of styles and is full of ideas, as well as musical styles of particular periods interpreted in various ways. Although many of his early ideas and concepts are present in his mature style, during the past few decades, Davies' musical writing gradually developed into more subtle and accessible ways.

This study therefore explores Davies' allusions to past practices in a contemporary context in his Naxos Quartet No. 8 (2005). The work demonstrates not only his musical vocabulary and handling that are familiar to pre-Romantic music practices but also musical ideas that give rise to his originality. He experiments with renaissance polyphonic writing and medieval practice, modifying them to make them modern in his composition. Davies' revisiting of Baroque English can also be seen in his musical elements that are derived from John Dowland's Queen Elizabeth's Galliard, joined with musical styles and ideas from Henry Purcell (1659-1695). Indeed, in the quartet Davies successfully recreated and transformed musical idioms of the past, with his own sounds and methods.

1 Quote taken from "Sir Peter Maxwell Davies, composer - obituary," The Telegraph, 14 March 2016. (Accessed: 17 March 2016) http://www.telegraph.co.uk/news/obituaries/12159467/Sir-Peter-MaxwellDavies-composer-obituary.html

2 Peter Maxwell Davies, "Is anybody listening? Reflections on the composer's relationship with society today," Maxopus.com, May 1995. (Accessed: 24 March 2016) http://www.maxopus.com/resources detail.aspx?key=10 
What is interesting in this quartet is that the music is arranged in a unique formal structure, as a combination of ideas derived from Classical and earlier periods of instrumental works and contemporary creativity, stamped with Davies' own structural design. Fragmentations are also created through frequent changes of tempo and textures. Throughout the composition, Davies makes choices about how to present ideas that are intriguing and informative, revealing musical relationships among musical elements.

Davies draws on various influences in the music, one of which is Beethoven-like musical language. For example, there are moments in the Quartet when Davies creates a sense of space through pitch-range that can be related to some of the works of Beethoven in which Beethoven divides the music into clear high and low pitches. In Davies' quartet an audible effect of distinctive high and low pitch is achieved through careful design. In addition, Davies creatively manipulates both past and contemporary rhythmic profiles, including various types of hemiolas. This flexibility and freedom in the music shows Davies constantly employing his creative imagination.

But this creative freedom is not limited to structure, spacious effect and rhythm. Davies was also attracted to using 'tonality' in his music, though not in the sense of proper harmonic progression found in the common practice of musical composing strategies. In Quartet No. 8, unlike many of his other compositions, Davies does not use the plainsongs, but is able to experiment with musical writings that are reminiscent of the medieval musical style. Indeed, the Quartet evokes associations with both the distant past and the present. All these present a distinctive character to the composition. Thus, it is valuable to explore the links between old and new musical idioms.

Although Quartet No. 8 is the shortest in length among all of Davies' ten Naxos quartets, it nevertheless demonstrates his mature musical writing style. That Davies chose to write such a short quartet suggests that it must contain some particular procedures that he had in mind. The musical effect is economy, yet insightful, showcasing Davies' distinct stylistic approach.

\section{The Ten Quartets}

Throughout his compositional career, Davies wrote in every genre, ranging from orchestral, chamber, opera, music theatre, oratorio and ballet. He has provided a very large repertoire to research and from which to learn. Among all his music, the ten Naxos quartets are undoubtedly a remarkable achievement in his oeuvre. "These series of Strathclyde concertos and 10 string quartets, it's too good to be true. One can't write 10 string quartets. One can, with luck, write one that is halfway reasonable," said Alexander Goehr. ${ }^{3}$

Davies claims that "the quartets are rather like a novel in ten chapters - the same rhythmic patterns, themes and harmonic designs are developed like characters through-

3 Quote taken from Stephen Moss, “Sounds and Silence," The Guardian, 19 June 2004. (Accessed: 12 August 2015) http://www.theguardian.com/music/2004/jun/19/classicalmusicandopera.proms2004 
out, also the same magic square matrices, and architectural structures carry over from one quartet to the next." However, the "novel" does not have a proper ending. In fact, it doesn't end. "The big decision, upon facing the last of the quartets for Naxos, was whether this should be a grand finale or not [...]," said Davies. "When it becomes clear how the movement might finish, the resolution is left to the listener's imagination: the dance is simply stopped, with a suspended gesture. This is not a finale - the hornpipe could lead straight back to the opening of Naxos Quartet No. 1, or into something as yet unwritten. There is no double bar-line." ${ }^{5}$ This compositional handling brings to mind "Im wunderschönen Monat Mai" in Schumann's Dichterliebe, in which the music ends on a dominant seventh, without a proper tonic resolving chord, longing for eternal renewal.

The ten quartets were written from 2002 to 2007. "I have been writing orchestral pieces solidly for 10 years. Now I'm desperate to get on with some chamber music. The appeal of the medium is in its concentration," said Davies. ${ }^{6}$ Of all the ten quartets Davies treats Quartet No. 8 as an "intermezzo." He also remarks that "the work ends quiet and intense - as if the experience of 'liberating' the John Dowland galliard had brought a temporary resolution and pause in the ongoing quest of the ten quartets," said Davies. ${ }^{8}$

Traditionally, there are several uses in past eras for the insertion of intermezzi; for example, they can function as "a means of clarifying the division of the play into acts," to unify a theme for one performance, or to connect them with the play in some way. ${ }^{9}$ However, intermezzo can also be a complete work in itself, as in those of the 18th century. In Quartet No. 8, Davies embraces the "intermezzo" as a work to connect the ten quartets; some of the musical characteristics from the early Naxos quartets are recalled and presented differently in Quartet No. 8.

Indeed, there are many recognizable traits in the ten quartets; some musical ideas and characters are foreshadowed, or echoed in the later ones. Above this, what all the quartets have in common is that they show one way or the other, that in musical composing there can be reference to common practice eras and earlier musical elements, idioms, styles and formal structures. For example, some movements of Davies' Quartets Nos. 1, 2 and 5 employ a Classical structural model. Davies remarks that "the exposition of this first

4 Peter Maxwell Davies, “Programme Note,” Music Sales Classical. (Accessed: 13 January 2016) http:// www.musicsalesclassical.com/composer/work/11861

5 Peter Maxwell Davies, “Peter Maxwell Davies: Naxos Quartet Nos. 9 and 10,” Perf. by Maggini Quartet. Compact disc, Naxos 8.557400.

6 David Ward, "Naxos Calls the Tune for Maxwell Davies," The Guardian, 25 March 2000. (Accessed: 12 August 2015) http://www.theguardian.com/culture/2000/mar/25/artsfeatures2

7 Peter Maxwell Davies, “Programme Note,” Music Sales Classical. (Accessed: 13 January 2016) http://www.musicsalesclassical.com/composer/work/11861

8 Ibid.

9 David Nutter, “Intermedio.” Oxford Music Online. (Accessed: 1 April 2015) http://www.oxfordmusiconline.com/subscriber/article/grove/music/13831?q=intermedio\&search=quick\&pos=1\&_ start $=1 \#$ firsthit 
movement [in Quartet No. 1] is based on classical models: Haydn looms large, with energetic first subject, and a more contemplative second subject group." 10 No. 5 is in a sonata form-like structure, with a slow introduction, an exposition, a short and dramatic development, and a shortened version recalling the introduction and exposition in a recapitulation section. Davies claims that "I've always, always, always kept my sights on Beethoven, Mozart, Haydn." 11 To him,

These composers articulated the structure, or architecture of a symphony, concerto, quartet or sonata in their particularly monumental way, dependent upon the rhetoric of tonality, whose possibilities were ever being explored, pushing back the frontiers with each new major work. During the nineteenth century the undermining of the tonic note which pinned the whole structure together so clearly became steadily more drastic $[\ldots] .{ }^{12}$

One also finds Davies uses plainsongs, polyphonic techniques, fugal style (including stretto), classical-like structures (such as sonata form, and scherzo and trio) and many other related musical genres and languages such as passacaglia (in Quartet No. 2), Scottish tunes and Renaissance passamezzo (in Quartet No. 10). To create sound colors and effects, Davies also employs quarter-tone in his Quartet No. 10, and in Quartet No. 9 techniques such as glissandi, high pitches, dense and rapid string writing generate tension, capturing the sound of air-raid sirens and exploding bombs. "The raw sounds of war-time Manchester that I heard as a small boy, and associated with that music - air-raid sirens, the 'glissandi' of falling bombs, the tearing apart of crashing buildings - but all re-interpreted, sublimated and disciplined within terms of the string quartets [...]." ${ }^{13}$

Davies knew well about modernist music in his early career. In fact, in the 1960s, he was seen as a European modernist composer. ${ }^{14}$ Indeed, his Eight Songs For A Mad King (1968) initially shocked critics and listeners. He once said, "I've been influenced by so many things-very notably the new music that interested me when I was young. At the

10 Peter Maxwell Davies, "Peter Maxwell Davies: Naxos Quartet Nos. 1 and 2," Perf. by Maggini Quartet. Compact disc, Naxos 8. 557396.

11 Jeremy Siepmann, “On Wings of Song: Peter Maxwell Davies talks to Jeremy Siepmann,” Naxos, 1 July 2012. (Accessed: 7 January 2016) http://www.naxos.com/news/default.asp?op=997\&displayM enu $=$ Interviews\&type $=2 \#$

12 Peter Maxwell Davies, "Religion and Politics: A Creative Involvement," Maxopus.com., November 2005. (Accessed: 24 March 2016) http://www.maxopus.com/resources_detail.aspx?key=29

13 Peter Maxwell Davies, "Peter Maxwell Davies: Naxos Quartet Nos. 9 and 10," Perf. by Maggini Quartet. Compact disc, Naxos 8.557400.

14 Ivan Hewett, "Peter Maxwell Davies: The Old Rebel has a New Cause," The Telegraph, 6 June 2012. (Accessed: 13 August 2015) http://www.telegraph.co.uk/culture/music/classicalmusic/9314713/ Peter-Maxwell-Davies-The-old-rebel-hasa-new-cause.html 
Darmstadt Summer School I met people like Messiaen, Boulez, Lutosławski." ${ }^{15}$ In a 2010 interview, Davies also claimed that, "I tried to make something constructive out of it learn what I possibly could, particularly from Stockhausen - and Luigi Nono, and Bruno Maderna, and Luciano Berio became very good close friends." ${ }^{16}$ Nevertheless, Davies also added that, "despite being fascinated by the avant-garde during the Fifties and Sixties, I've always been aware that anyone making music has a social duty and a contract [...] There's never a good enough excuse for writing music that audiences don't like." ${ }^{17}$ Perhaps with this awareness in mind, Davies made a turn toward more approachable musical language.

Most commonly found in Davies' quartets is his reference to pre-classical musical styles, in particular the Medieval and Renaissance periods. For example, his Quartet No. 3 not only draws on Audi, filia, et vide, a plainsong gradual hymn for St. Cecilia's Day, but also the second movement demonstrates Davies' heavy use of the polyphonic technique. Other quartets that use plainsongs include the second movement of Quartet No. 6, which is based on an Avert plainsong, and Quartet No. 7. Not surprising, plainsongs became experimental sources for Davies.

Indeed, Davies has never lacked ideas for his music, he draws inspiration from things he had encountered. For instance, musical ideas drawing from Renaissance architectural constructions can be seen in his Quartet No. 7. Not only does Davies entitle each movement with reference to Italian church architectures designed by Franceso Borromini (1599-1667) such as "San Carlo alle Quattro Fontane I," "San Giovanni dei Fiorentini, Chiesa Inferiore," "San Giovanni in Laterano," but also introduces techniques such as spacious effects and plainsong to create images of the architectural structures.

Moreover, at young age Davies was attracted to the sounds of the Medieval and Renaissance periods. "When I was very young, it was the sheer sound of that late mediaeval and Renaissance music [that attracted me]. I used to go most weekdays when I lived in Manchester to services in Manchester Cathedral, where I heard wonderful Renaissance music," said Davies. Thus his music background and training also play an important role in the development of his composing. Davies recalled,

At University I sang in the university madrigal choir-lots and lots of madrigals, English and Italian ones, Palestrina masses, and the masses by William Byrd, which remain a great

15 Jeremy Siepmann, “On Wings of Song: Peter Maxwell Davies talks to Jeremy Siepmann,” Naxos, 1 July 2012. (Accessed: 7 January 2016) http://www.naxos.com/news/default.asp?op=997\&display Menu=Interviews\&type $=2 \#$

16 Nicholas Jones, "Peter Maxwell Davies in the 1950s: A Conversation with the Composer," Tempo, Vol. 64, No. 254 (October, 2010): 16.

17 Ivan Hewett, "Peter Maxwell Davies: The Old Rebel has a New Cause," The Telegraph, 6 June 2012. (Accessed: 13 August 2015) http://www.telegraph.co.uk/culture/music/classicalmusic/9314713/ Peter-Maxwell-Davies-The-old-rebel-hasa-new-cause.html 
influence on me. Then when I went to study in Rome in the 60s I immersed myself in plainsong, which has permeated my work. ${ }^{18}$

As a composer, Davies sees the use of plainsong as a prevailing trend of his time:

I think using those plainsongs is something like an icon, that many people have had contact with, and these things have gone through the imaginations of many many composers, and have fertilised imaginations in all kinds of ways. In many ways this music seems to me as contemporary as the composers of our own time. ${ }^{19}$

The use of plainchant in Davies' music can be heard as early as in his St Michael (1957) and the motet Ecce Manus Tradentis (1964).

\section{Naxos String Quartet No. 8}

This quartet is a tribute to the Elizabethan lutenist and composer, John Dowland. To celebrate the Queen's 80th birthday Davies quotes Dowland's Queen Elizabeth's Galliard in the music, and the composition is dedicated to the Queen. It was first performed on $10^{\text {th }}$ March 2006 by the Maggini Quartet, at St. Gregory's Center, Canterbury Christ Church University, Canterbury, as part of the Sounds New Festival.

Like many modernist composers, fragmentation, distortion and parody techniques have been part of Davies' musical styles since the 1960s. Stephen Pruslin, a fellow student who became a friend and collaborator, claims that in the late 1960s Davies "raised stylistic disruption to an artistic principle [...] taking plainsong and distorting and parodying it [in his Missa super L'Homme Armé (1968)]." ${ }^{20}$ Other of his compositions such as Fantasia on a Ground and Two Pavans (1968) and Strathclyde Concerto No. 6 (1991), also employed the parody technique. Indeed, Davies asserts that "parody has been central to much of my work, in both its original meaning - as in early parody masses, where the new work simply borrowed from and built upon material from another work - and in its modern meaning of 'sending up' a work or style to which the new work refers." ${ }^{21}$

Davies also employs the parody technique in Quartet No. 8. The original theme of the Galliard is less directly presented at the beginning of the composition. Melodic fragments of the theme are scattered throughout the music in distorted form; in most cases, they are

18 Jeremy Siepmann, “On Wings of Song: Peter Maxwell Davies talks to Jeremy Siepmann,” Naxos, 1 July 2012. (Accessed: 7 January 2016) http://www.naxos.com/news/default.asp?op=997\&display Menu=Interviews\&type=2\#

Ibid.

20 Stephen Moss, "Sounds and Silence," The Guardian, 19 June 2004. (Accessed: 12 August 2015) http://www.theguardian.com/music/2004/jun/19/classicalmusicandopera.proms2004

21 Peter Maxwell Davies, “Composition questions answered - 2 of 4," Maxopus.com., January 2006. (Accessed: 24 March 2016) http://www.maxopus.com/resources_detail.aspx?key=32 
placed in a contemporary context and are not easily detected without careful listening. At times, pedal point, a sustaining bass which is popularly used by Baroque and Classical composers, is employed to accompany the fragment of the Galliard, drawing attention to the listeners, and this can be heard at beginning measures 228-234 (Example 1).

\section{Example 1}
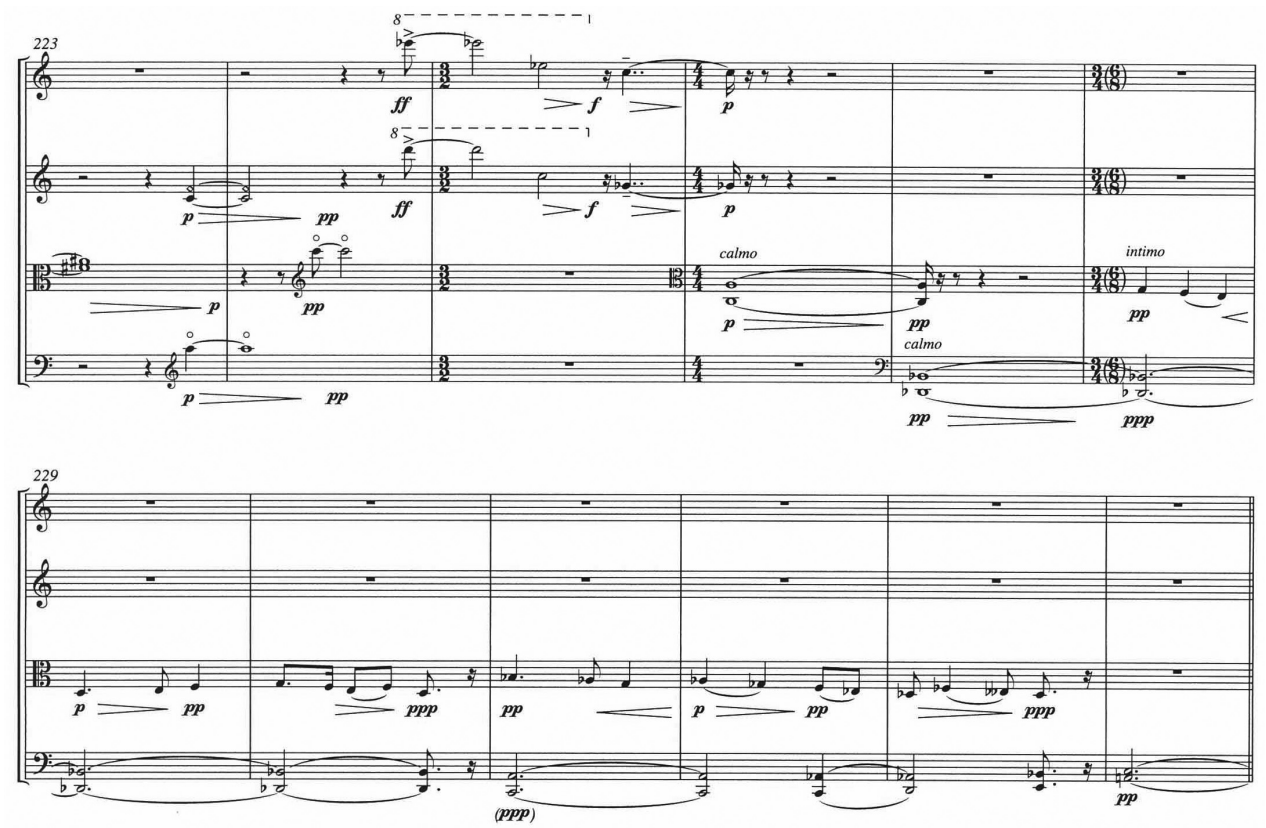

Davies certainly plays around with the Galliard melody before its full appearance at measure 263. Throughout the composition musical gestures such as lively long-short rhythmic patterns, a leap in between two notes, and fast, running sixteenth-notes in ascending and descending forms are derived from the Queen's melody. All these form a successful unity to the quartet.

Many of the ideas used in the quartet can be referenced to the music of Purcell. Davies keeps to the idea of many of Purcell's trio sonatas where adagio and grave are often used to indicate the opening of his pieces; Davies' quartet begins with a slow, short threenote (G\#-A-C) in adagio molto, catching the attention of listeners. This three-note motif is transposed throughout the composition and also shapes the structure of the music. A somewhat similar opening is heard in Quartet No. 7 in which Davies uses adagio molto, except now it begins with four pitches (F-G-A flat-C). Both share the same pattern in the melodic contour of the last three notes: semitone and a leap of third. 
Quartet No. 8 is in single movement, but Davies divides the composition into two large roughly equal halves, with the first half from $\mathrm{mm}$. 1-153, and the second half from mm. 154-310. Perhaps such a design can also be referenced to Purcell, for as Peter Holman writes, "Purcell liked to create structures that are roughly but not exactly symmetrical." 22 Nevertheless, the second half of the quartet functions similar to a Classical "recapitulation" section, recalling material from the opening of a piece that is frequently found in the music of the common practice era. Not only does Davies recall the opening three-note motif (G\#-A-C) at measure 154, but also as the music progresses musical gestures-such as fast, running sixteenth-notes and trills-from the first half of the music are reintroduced. By drawing the attention to the arrival of the second half, Davies employs sustaining long-note values, soft dynamic level ( $(p p)$ ), followed by a quarter-note rest beginning at measures 150-153.

Davies' creative act is not limited to the two halves of a major division in Quartet No. 8. Changes of textures and ideas also are often employed to further divide the music into sub-sections. The use of this sectional idea can be seen in many early baroque musical compositions such as Purcell's Toccata in Suite No. 8, Piccinini's Ciaconna in parteite variate and early sonatas. Indeed, early models often lie behind Davies' approach to construct his formal structure.

In his Quartet No. 8, Davies extensively employs double-bar lines in the composition for section divisions as the music progresses. Nevertheless, beginning at measures 179 to 221, section divisions occur more frequently, with each section containing less than eight measure numbers. Different tempo is also applied in each section, creating contrast between each section. "Slow, moderate and fast sections alternate in a way derived from Purcell's string fantasias [...]," said Davies. ${ }^{23}$

|| mm.179-181 || 182-184 || 185-179 || 190-191 || 192-196 || 197-204 || 205-206 207-209 || etc.

Davies' English encounter can be traced back to his early Points and Dances from "Taverner" (1970) and First Taverner Fantasia (1962) and Second Fantasia on John Taverner's "In Nomine" (1964).

Moreover, Davies often uses pauses, rests, breath marks and double lines to indicate the change of ideas and events in the quartet. This in turn, at times, creates a sense of fragmentation. Such effect is particularly obvious at measures 15 and 25 where breath marking are used to indicate the change of ideas and textures.

22 Peter Holman, "Compositional Choices in Henry Purcell's 'Three Parts upon a Ground', Early Music, Vol. 29, No. 2 (May, 2001): 258.

23 Peter Maxwell Davies, “Peter Maxwell Davies: Naxos Quartet Nos. 7 and 8," Perf. by Maggini Quartet. Compact disc, Naxos 8. 557399. 
Like the musical tradition of pre-classical times, the music in Quartet No. 8 moves in linearity and with polyphonic in texture. There are times when melodic lines are notated diatonically, as if Davies had written it as a vocal work. In addition, each musical idea and event tends to move from simplicity to complexity; they begin with long-note values, less rhythmic activity, gradually adding shorter-note values to create more rhythmic activity. Much of the Renaissance's polyphonic music was written in this manner.

Although no musical text and plainchant melody are used in the quartet, Davies experiments with the musical handling; it is reminiscent of medieval practice in which the upper voice moves while the tenor holds one note. "Tenor" is a term used to indicate the fundamental voice part of a polyphonic composition in Medieval and Renaissance periods. Such a musical idea is introduced at measures $66-88$, but presented in a different way. The upper voices (violins 1 and 2), which play the role of "tenor" and "contra-tenor," move in somewhat static, long note-value in tremolo, while viola and cello are in forward moving, short-note value in a lively manner (Example 2). Davies presents an old musical idea with a different design.

\section{Example 2}
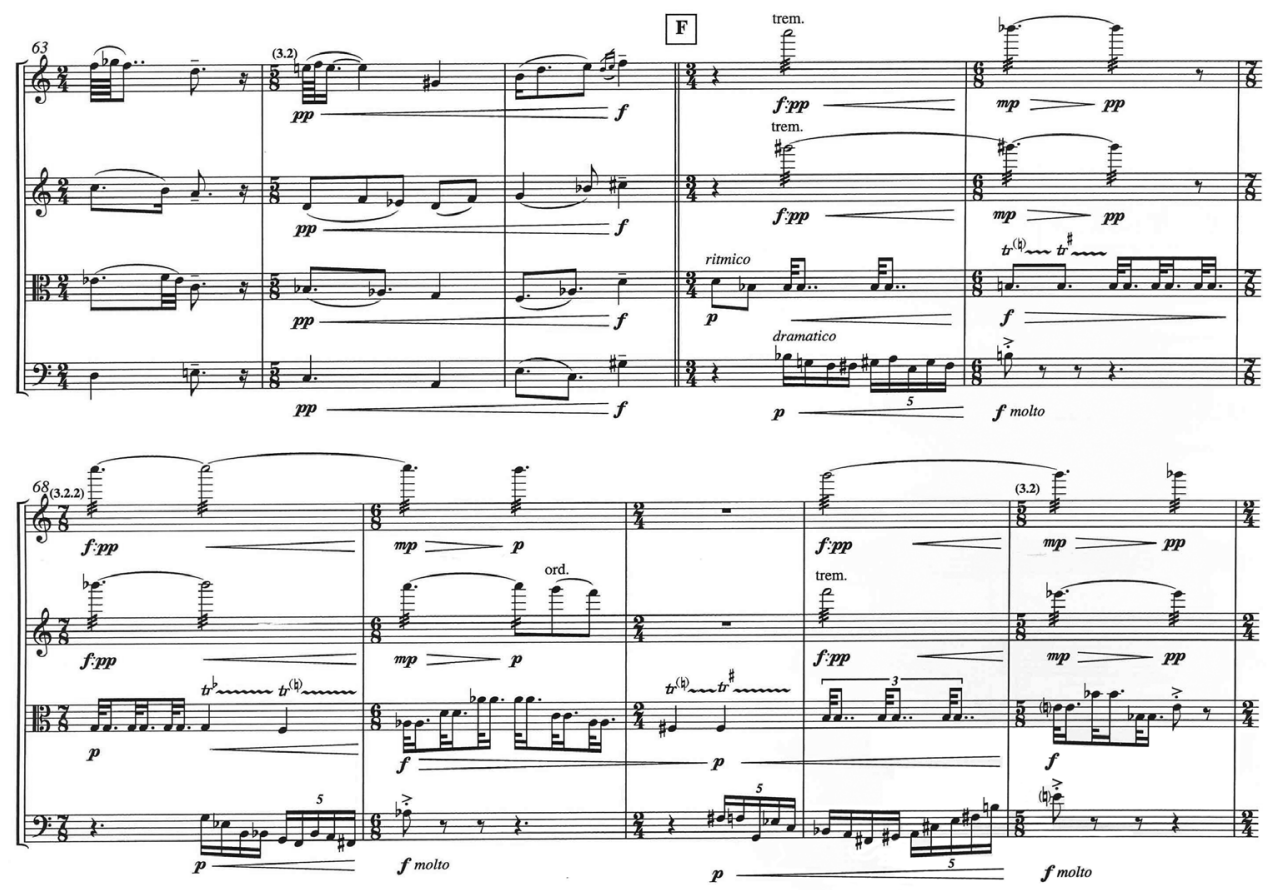
Such musical handling also shows that it is as if Davies intends to reintroduce the role of "tenor" as the principal voice; this can be traced back to the earliest presentation of principal voice and organal voice design in the medieval style, in which principal voice is placed above the organal voice.

In addition, there is a musical gesture where the tremolo accompaniment in the violins reminds one of the fourth movement in Beethoven's String Quartet No. 16 in F Major, op. 135. This is perhaps not surprising given that Davies have been studying the quartets of Haydn and Beethoven while writing these ten quartets. In 2004, during his writing of Quartet No. 6, Davies asserted that, "I have recently been studying again Beethoven's late quartets, and although I am well aware that I could never aspire to write work remotely approaching such as model, I trust these studies show through positively in the present work." ${ }^{24}$ Indeed, Davies' admiration for Beethoven can also be seen in many of his public speeches and his interviews with scholars. ${ }^{25}$ When asked about his most favorite Beethoven music, Davies answered: "two great fugues by Beethoven: the last movement of his Hammerklavier sonata, and the last movement of his late B flat quartet." 26

Significantly, Quartet No. 8 also employs the key model of Beethoven's Eroica. "It needs the whole quartet to find its 'real' identity: the models were the first and the last movements of Beethoven's Eroica, where the main theme is only joined up consecutively to make its full identity clear at the final climaxes. The tonal center is A - minor at the opening and major at the end," said Davies. ${ }^{27}$

The influence of Beethoven also extends to Davies' Quartet No. 1. Davies acknowledged that "the first slow movement of the Quartet [No. 1] recalls the mood of the start of Beethoven's F sharp major piano sonata [...]." ${ }^{28}$ It is not surprising, then, that some influences from Beethoven also appear in Naxos Quartet No. 8, although handled differently.

24 Peter Maxwell Davies, “Peter Maxwell Davies: Naxos Quartet Nos. 5 and 6," Perf. by Maggini Quartet. Compact disc, Naxos 557398.

25 Peter Maxwell Davies, "Religion and Politics: A Creative Involvement," Maxopus.com, November 2005. (Accessed: 24 March 2016) http://www.maxopus.com/resources_detail.aspx?key=29. Anna Edwards, "Queen's composer says every young person should study classical music after branding it 'disgraceful' that many do not know who Mozart is," Daily Mail Online, 18 November 2013. (Accessed: 13 August 2015) http://www.dailymail.co.uk/news/article-2509136/Queens-composerPeter-Maxwell-Davies-wants-young-people-study-classical-music.html. "Peter Maxwell Davies Talking to Composer Sir Peter Maxwell Davies and Conductor Christopher Austin at the Livorno Music Festival," Livornonow, August-Sept 2013. (Accessed: 31 March 2016) http://www.livornonow.com/ talking_to_composer_sir_peter_maxwell_davies_and_conductor_christopher_austin_at_the_livorno_music_festival

26 Laura Barnett, "My Advice to a Young Musician? Take No Notice of People Like Me," The Guardian, 16 June 2009. (Accessed: 12 August 2015) http://www.theguardian.com/culture/2009/jun/16/ peter-maxwell-davies-composer

27 Peter Maxwell Davies, “Peter Maxwell Davies: Naxos Quartet Nos. 7 and 8," Perf. by Maggini Quartet. Compact disc, Naxos 8. 557399.

28 Peter Maxwell Davies, “Peter Maxwell Davies: Naxos Quartet Nos. 1 and 2,” Perf. by Maggini Quartet. Compact disc, Naxos 8. 557396. 
The fact is that tonal center and "tonic" and "dominant" harmonic systems are often experimented with in a non-traditional way in most of his Naxos Quartets. For example, in his Quartet No. 5, the music begins with a B-flat pitch, which Davies treats as a "tonic", and the movement ends in $\mathrm{C}$ minor tonality. His approach to tonality includes the use of a traditional notated key-signature with four flats for $\mathrm{F} \#$ minor, which can be seen in his Quartet No. 6.

Davies remarks that "my thinking has always been tonal, even when it seems to be atonal on the surface." ${ }^{29}$ Beginning in the mid-1970s the idea of "tonics" and "dominants" "has marked the inception of a 'tonal' practice that has since developed to become an integral part of his unique and highly individual compositional technique." ${ }^{30}$ Moreover, Davies believed that his experience as a conductor conducting the classical repertoire with the Scottish Chamber Orchestra had influenced his approach to harmonic writing. ${ }^{31}$

Davies always shows alternative ways in presenting one idea or musical style. Another obvious musical treatment in Quartet No. 8, that derives from the Medieval musical style, can be seen at measures 123-129, where a static voice in the cello is employed to accompany the other three energetic voices (Example 3). Unlike the medieval tenor part, where it is placed in a low voice, in this quartet the cello functions as the "tenor" and is presented in harmonics and high pitches. In addition, stepwise motions in long-note values that are often found in the medieval tenor voice part are introduced in ascending form. Rhythmic vitality such as the frequent use of triplets and quintuplets also suggests the rhythmic profile introduced by Petrus de Cruce's motets, such as Aucun ont trouvé/ Lonc tans/Annuntiantes, and Je cuidoice/Se j'ai folement/Solem.

29 Ivan Hewett, "Peter Maxwell Davies: The Old Rebel has a New Cause," The Telegraph, 6 June 2012. (Accessed: 13 August 2015) http://www.telegraph.co.uk/culture/music/classicalmusic/9314713/ Peter-Maxwell-Davies-The-old-rebel-hasa-new-cause.html

30 Nicholas Jones, "Peter Maxwell Davies's Basic Unifying Hypothesis: Dominant Logic," The Musical Times, Vol. 143, No. 1878 (Spring 2002): 37.

31 Stephen Pruslin and Peter Maxwell Davies, “Peter Maxwell Davies's Symphony No. 4,” The Musical Times, Vol. 130, No. 1759 (September 1989): 520. 


\section{Example 3}
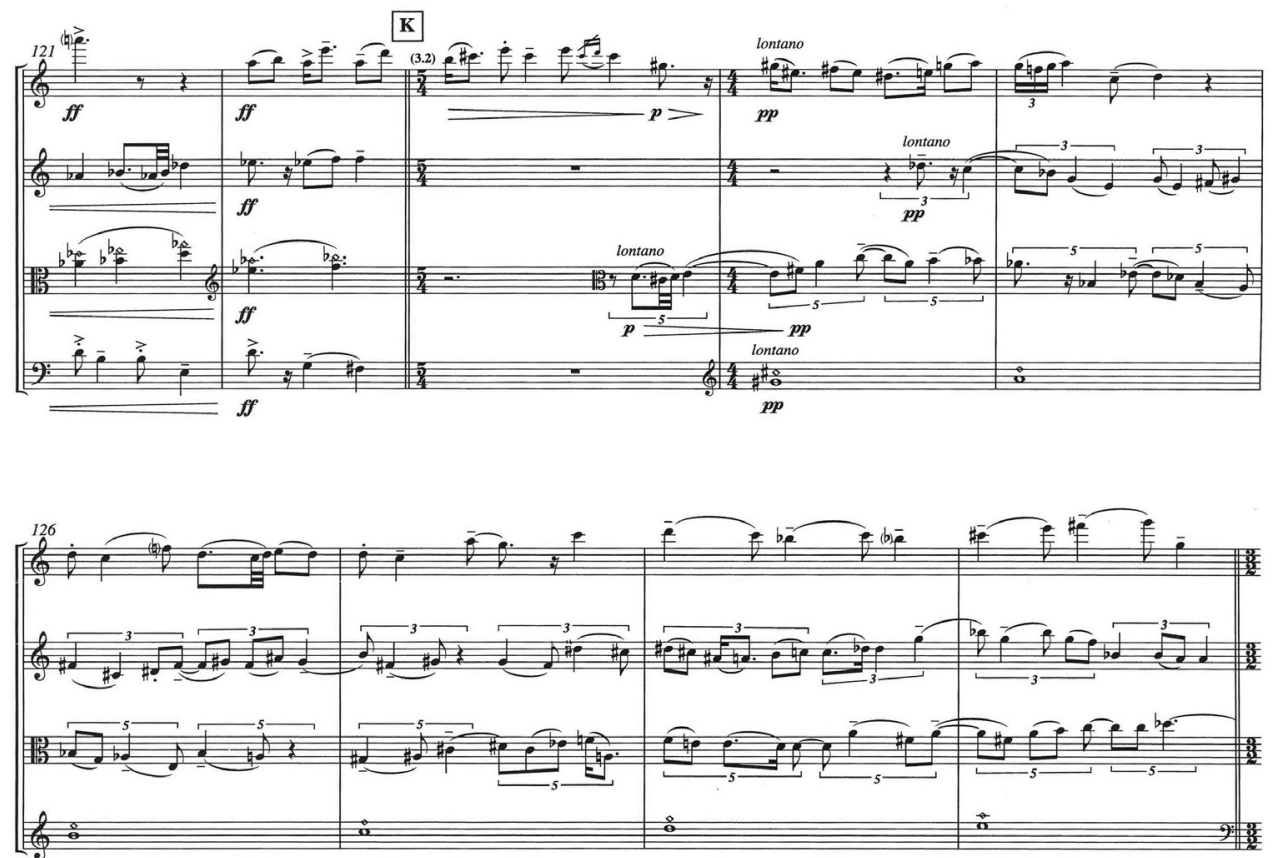

Indeed, rhythms have played a significant role in the music of Quartet No. 8. The Baroque Lombardic rhythmic pattern, and dotted rhythms which are a hallmark of Davies, are obsessively used throughout the composition. Davies certainly was aware of dotted rhythms as one of the English styles in the Baroque period. The predominant use of dotted rhythms can be found in early English composers such as Purcell, John Jenkins, Matthew Locke, John Playford, and many others.

Davies also showed strong interest in syncopated sound created by hemiola. In art music, hemiola was commonly used up to the late Baroque period. Robert de Handlo once wrote, that "the interest in rhythm was strong also in England is seen in the fact that syncopation is first mentioned in an English treatise of 1326 [...]." ${ }^{32}$ Nevertheless, hemiola is also popular in African and pop music. Types of hemiola are experimented with in the Quartet No. 8. For example, at measure 44, two quarter-note dotted rhythms are notated in a 3/4 time-signature. Other clear hemiola examples include juxtaposing/horizontal hemiola of $6 / 8$ and 3/4 at measures $186-187$ and simultaneous/vertical hemiola of $6 / 4$ over 3/2 at measures 197-198 (Example 4). A combination of the two types can also be heard beginning at measure 199 , providing a different listening experience.

32 Quote taken from Andrew Hughes, "Mensuration and Proportion in Early Fifteenth Century English Music,” Acta Musicologica, Vol. 37, Fasc. 1/2 (January - June 1965): 50. 


\section{Example 4}

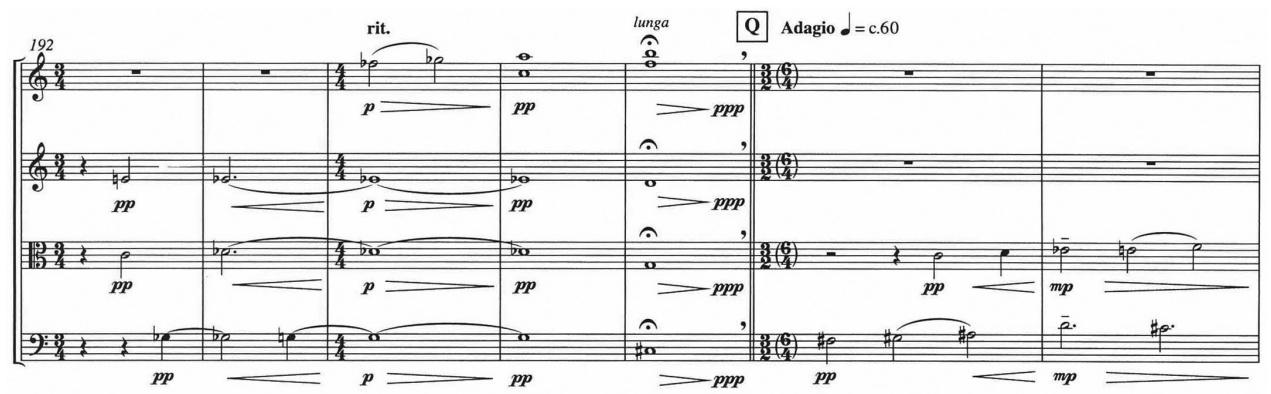

However, not all rhythmic ideas in the quartet are derived from the past musical idioms. Apart from frequent shifting of both conventional and unconventional time-signatures such as $2 / 4+9 / 16,7 / 4$ and $5 / 8$, there are times when accented markings are placed on weak beats to create a lively mood. Off beats are also stressed to create syncopation and liveliness in rhythms that are often found in jazz and popular music. As a composer, Davies disliked popular, minimalist music. "It's all so repetitive," and "there's no proper development," he said. ${ }^{33}$ Nevertheless, he wrote pieces such as St. Thomas Wake (1969) and Mavis in Las Vegas (1994) in the style of foxtrot and big band sound, respectively. To some extent, Davies also aimed to write music that was more accessible to general audiences. In particular, since 2004, after he had become the Queen's composer, Davies said, "I've kept her [the queen] in mind as part of my challenge to address listeners who are genuinely interested in music but not specifically in the new. There's no point writing something the queen or whoever will attend and giving them a rotten time." ${ }^{34}$

There are times when spacious effects are created through screaming high pitches separated from the low pitch range, dividing the music into the upper pitch and lower range. A clear example is at measures 5 to 7 where violin $I$ is presented in extreme high pitches F\#7-G7-A7-G7-F\#7 (based on middle $\mathrm{C}$ as $\mathrm{C} 4$ ), distinguishing them from low pitches ranging from A3 to $\mathrm{G} 6$ in violin 2 and viola. This musical handling also brings to mind of some of Beethoven's compositional treatment in his string quartets. For instance, there are moments in the fourth movement of Beethoven's String Quartet No. 8 in E Minor, op. 59, no. 2, in which an obvious high pitch range is introduced in the violin 1, separating it from the other three instruments and creating a spacious effect. Davies could have designed a less obvious pitch range distinction by placing pitches within two octaves that is found in most of Haydn's string quartets, but he chose to experiment with

33 Ivan Hewett, "Peter Maxwell Davies: The Old Rebel has a New Cause," The Telegraph, 6 June 2012. (Accessed: 13 August 2015) http://www.telegraph.co.uk/culture/music/classicalmusic/9314713/ Peter-Maxwell-Davies-The-old-rebel-hasa-new-cause.html

34 Quote taken from Michael White, "The Queen's Composer, but Ever Unbowed," The New York Times, 23 January 2009. 
spatial quality in his music. Another clear example of Davies' can be heard in the second movement of his String Quartet No. 7 at measures 12-15. Such musical handling became one of Davies' typical language modes.

Since the Quartet No. 8 is a tribute to John Dowland, some recognizable lute styles are necessary in the music. Davies imitates the lute style by employing rolled chords (a vertical wavy line), in which notes are played quickly in order, as opposed to simultaneously. Pizzicato is also employed to project the pluck-string sound of the lute. At times, a diatonic melodic contour within an octave range, that is often found in Dowland's music, is imitated here.

\section{Conclusion}

The series of the ten quartets is held together by ideas, idioms and styles, but flexibly introduced in various ways. Each shows connection to one another in musical style, yet each can also be differentiated from others, retaining its individuality. For Davies there is never a lack of ideas in composing. Many renewals of pre-classical musical language can be seen in the quartets, showing Davies as keenly engaged with past practices but within contemporary musical contexts.

Quartet No. 8 is short, yet challenging to listeners. Davies has built his own vocabulary by borrowing heavily from the past; he has creatively employed musical idioms from Baroque and earlier, with which he was familiar and to which he was deeply attracted. Davies experiments with the design of the fundamental idea of "tenor", including the earliest medieval principal and organal design. Not only does he venture with the practices of medieval "tenor" in various ways, but also several treatments in Quartet No. 8 suggest a Beethovenian style of writing. Davies observes Beethoven's musical handling of spatial distinction and carefully interprets this in his Quartet.

The composition not only demonstrates Davies' interpretation of Dowland's musical writing and his Queen Elizabeth's Galliard, but also lute styles are carefully imitated in the composition. Many of the musical characteristics such as dotted rhythms and diatonic, which may seem common and less important in a composition, have now turned into a language that alludes to an English musical style. Davies translates these traditional features into a more contemporary context. Indeed, although the composition may sound like a pot of every musical style of different periods stirred together, Davies certainly provides musical characteristics that can one recognize as the composer's own voice and distinct from others.

Davies' concern in his Quartet is not merely about many musical styles and handlings drawn together, but importantly about unity in the composition. He not only uses musical elements that are derived from the Galliard, but also different transpositions of the opening three-note pitches provide a sense of underlying connection throughout the composition. 
Logical structural connection in the music can also be seen in Davies' acknowledgement of the Classical tradition manifested in his establishment of harmonic-like rules and "tonality." Structure is carefully constructed through combining both traditional and Davies' own musical designs, calling for a different way of classical "recapitulation" sectioning in the quartet. Indeed, although his quartet is contemporary in sound, it connects both past and present, in which selected musical sources and ideas are informative.

While pre-romantic spirits are clearly present, the music sounds contemporary; his stress on techniques such as hemiola, frequent change of meters, fragmentation and distortion are seen in the Quartet. Each of these are parts of Davies' individual musical language. Despite all Davies' experimentation in the quartet, the music sounds accessible and approachable. Audiences are challenged in many ways by Davies' presentation of his musical ideas. Indeed, Davies offers the possibility of a meaningful past in his contemporary context.

\title{
Peter Maxwell Davies' Interpretation of Past Musical Practices in Naxos Quartet No. 8
}

\begin{abstract}
This study explores Davies' allusions to past practices in a contemporary context in his Naxos Quartet No. 8 (2005). The work demonstrates Davies' experiments with Renaissance polyphonic writing and Medieval practice, modifying them to make them modern in his composition. Baroque English musical elements in the composition are derived from John Dowland's Queen Elizabeth's Galliard, joined with musical styles and ideas from Henry Purcell (1659-1695). Logical structure of Classical period is also employed in the music. Listeners are certainly challenged in many ways by Davies' musical language in the composition.
\end{abstract}

\section{Reflexe hudební praxe staré hudby v díle Naxos Quartet $\check{c} .8$ skladatele Petera Maxwella Daviese}

\begin{abstract}
Abstrakt
Studie reflektuje kompoziční praktiky tzv. staré hudby v díle Naxos Quartet č. 8 (2005) skladatele Petera Maxwella Daviese. Text ukazuje skladatelovy experimenty s renesančním polyfonní i se středověkou hudbou, respektive jejich modernizace $\mathrm{v}$ rámci jeho aktuální tvorby. Anglické barokní hudební prvky jsou v dané kompozici odvozeny z díla Johna Dowlanda Queen Elizabeth's Galliard, zde se fúzují s hudebními myšlenkami Henry Purcella (1659-1695). Hudba období klasicismu se u Daviese objevuje také. V řadě ohledů vyvijí Daviesova hudba na posluchače nemalé nároky.
\end{abstract}




\section{Keywords}

Naxos Quartet No. 8; Peter Maxwell Davies; Twentieth-first Century Music.

\section{Klíčová slova}

Naxos Quartet č. 8; Peter Maxwell Davies; hudba 21. století. 